\title{
Sovereignty: History and theory
}

\author{
Raia Prokhovnik \\ Imprint Academic, Exeter, 2008, 234pp., £40.00/\$34.90, ISBN 978-1845401146
}

Contemporary Political Theory (2009) 8, 470-472. doi:10.1057/cpt.2009.27

Prokhovnik's two-volume study of the concept of sovereignty is an ambitious and uniquely conceived project (see her previous book Sovereignties: Contemporary Theory and Practice, Palgrave Macmillan, 2007). In method and substance there is of course considerable similarity. Both books present a very open kind of theorising, attuned to multiple interpretations and readings, incorporating political dialogue and contingency, and never legislating absolutes, precisely because human experience, not least politics, is so indeterminate. Prokhovnik's is a kind of theorising that genuinely promotes complexity and makes judgement possible and necessary, but not easy. Overall this is discourse-based work that enlightens and enlarges, and never pretends to 'nail things down'.

However, the two books also exhibit considerable differences and don't fit together easily. Indeed they probably have rather different audiences, though Prokhovnik's intentions (for what an author's intentions are worth) are not particularly clear on this point. The earlier work seems targeted at a community conversant in theory that relates to contemporary politics and concerns, specifically institutional ones involving the defence or dispersion of sovereignty. For this one must have a grasp of what sovereignty is said to mean - and can be said to mean - in the first place. Perhaps surprisingly, for historically minded political theorists at least, the theoretical issues and debates were drawn from contemporary sources, chiefly in International Relations theory, with canonical histories and perspectives largely separated off into the later volume. Although necessarily rather abstract, the theorisation in the earlier book took on board the way that sovereignty functions in relation to the nation state, international politics and in a transformative and innovatory way, the European Union.

The present volume looks back to a selection of classic works, following the welcome insight that - sub-disciplinary claims notwithstanding - the division between the international as a political 'space', and the national or domestic, has little to recommend it, and was unknown before, or at least not theorised as a professionalising binary until, the twentieth century. It might seem that we are on familiar canonical and chronological ground here, commencing with the chapter 'Bodin and Before'. However, Prokhovnik's selection of classic authors is grouped in a novel way in pairs: Hobbes and Spinoza, Locke and 
Rousseau, Kant and Hegel, and then in a swift update to contemporary concerns, Schmitt and Foucault. The thinkers are handled contextually but allowed to generalise, and the pairwise treatment allows some novel points of comparison. What holds the work together comes out best in the concluding chapter, where Prokhovnik explains that sovereignty is extracted and evaluated in relation to a concept of 'the political'. She outlines this persuasively, distinguishing it from any facile reflection or endorsement of 'liberal democracy' as such. Both books share this perspective, and with luck, the two works might enable even 'International Relations (IR) realists' to talk to post-structuralists, taking two extremes - supposing they wanted to. Prokhovnik has thus nominated sovereignty as a point of contact across the spectrum of theory communities, showing that the concept is conceptualised differently but is indubitably important across the board (even when its function is that of a radical 'other', as with Foucault). Sovereignty thus has a future, as well as a history.

My critical comments on this enterprise are perhaps more a matter of taste than of serious objection. Unsurprisingly I missed Marx in the line-up of thinkers, especially given that his detailed critique of Hegel's political theory gets an accurate and respectful airing in the relevant section. If we can have Foucault as an 'other' to sovereignty, why not Marx as well? Although 'the political' is well set out as a conception, with appropriate reference to Connolly, Mouffe and Rancière, I find the discourse determinedly abstract and in the end, difficult to 'envision'. Elsewhere in the book we get some helpful illustration linking abstractions to more substantive political discourses. The discussion of the US constitution in the Locke chapter, for instance, was something I particularly enjoyed, along with the earlier contextualisation of Spinoza in relation to the politics of the United Provinces.

Perhaps rather more controversially I felt I needed more contact with the chosen author's own texts, and so found a discourse rather dominated by commentators' paraphrases (or claims?) tiring at times. Is the commentator right? But what is the commentator's project? Are we sure that it fits Prokhovnik's reading? Why does the author not speak for himself? Unsurprisingly the canonical authors here are all male - or perhaps that is surprising. The issue isn't mentioned. Indeed the gender dimension seems not to figure in these discussions at all, even to show that (unlikely, I think) it couldn't be used to show us something.

Still, no one project is going to push on all the boundaries at once, and I can recommend the book to the wider theory community, most expressly including International Relations theorists, where the historical and canonical side of things isn't always well done. Moreover Prokhovnik's general views on how theory and history are intertwined with contemporary theorising and political practice cannot be endorsed too highly, and are particularly important 
discussions for students to read. I would like to get my students more interested now in practical discourses through which we can see the workings of sovereignty, and to use Prokhovnik's work to set their findings into a larger framework, richer in history and theory.

Terrell Carver

University of Bristol, Bristol, UK

\title{
Hobbes and republican liberty
}

\author{
Quentin Skinner \\ Cambridge University Press, Cambridge, 2008, 245pp., ISBN: 978-0521714167 \\ Contemporary Political Theory (2009) 8, 472-474. doi:10.1057/cpt.2008.62
}

In this elegant extended essay, Quentin Skinner returns to his familiar concerns with the character of republican liberty (with a rather wistful recognition that his own preference for the label 'neo-Roman' has now been overwhelmed by popular usage) and the political philosophy of Thomas Hobbes. Having briefly outlined the core component of the republican conception of liberty as 'nondomination', Skinner turns his attention in the rest of his essay to Hobbes's position as perhaps the single greatest critic of this republican view. He seeks to show how Hobbes's view of liberty changed from the Elements of Law (in 1640) to Leviathan (in 1651), indeed so significantly that the account in the latter could be considered a 'repudiation' of his earlier view. This change must, in its turn, be understood in terms of Hobbes's continuing and passionate engagement with the supporters of constitutional or limited government and his insistence upon the need to resist radical and republican reformers in the name of social peace.

In discussing the nature of liberty in the Elements of Law, Hobbes sets out his own very distinctive (radically anti-Aristotelian and anti-scholastic) account of the passional nature of the will as "nothing other than the name of the last appetite or fear that brings deliberation to an end' (p. 25). In the state of nature, we are free to act 'at will' but at the same time we have a natural tendency to do that, which will contribute to our self-preservation. The state of nature is characterized by 'a right of every man to every thing' and there are no limits upon what any man may do (to any other) in order to secure that which he wills. Of course, according to Hobbes, this is a 